\title{
Trophic structure of shallow-water benthic communities in the sub-Antarctic Strait of Magellan
}

\author{
Claudia Andrade ${ }^{1,2} \cdot$ Carlos Ríos $^{2} \cdot$ Dieter Gerdes $^{1} \cdot$ Thomas Brey $^{1}$
}

Received: 3 June 2015/Revised: 31 December 2015/Accepted: 12 January 2016/Published online: 21 January 2016

(C) Springer-Verlag Berlin Heidelberg 2016

\begin{abstract}
Trophic structure is among the most fundamental characteristics of an ecosystem since it is a useful way to determine the main energy flow at the ecosystem level. In the Magellan Strait, the local spatial heterogeneity at the shallow-waters ecosystems may have a great variety of potential food sources; however, knowledge about their biological communities and their structure is still unclear. We examined the trophic structure of shallow-water-mixed bottom communities at two sites in the sub-Antarctic Magellan Strait based on carbon $\left(\delta^{13} \mathrm{C}\right)$ and nitrogen $\left(\delta^{15} \mathrm{~N}\right)$ stable isotope ratios. The benthic communities were composed of 46 species from 20 major taxa at Bahía Laredo (BL) and 55 species from 18 major taxa at Punta Santa Ana (PSA). Benthic macroalgae and organic matter associated with sediment are the major primary food sources at both sites. Although both sites are quite similar in their food sources and in their vertical trophic structure ( $\geq$ three trophic levels), the food web structure varied distinctly. Functionally, predators and grazers dominated both communities, but top predators were shorebirds, carnivore anemones and predatory nemerteans at BL, and sea stars, shorebirds, crabs and fishes at PSA. The distinct differences in the trophic structure at BL and PSA highlight the important variability of $\delta^{15} \mathrm{~N}$ at the base of the benthic food web, the role of local environmental conditions and community dynamics in structuring shallow-water communities.
\end{abstract}

Claudia Andrade

claudia.andrade@umag.cl

1 Alfred Wegener Institute, Helmholtz Center for Polar and Marine Research, Am Alten Hafen 26, 27568 Bremerhaven, Germany

2 Instituto de la Patagonia, Universidad de Magallanes, Casilla 113-D, Punta Arenas, Chile
Keywords Benthic communities · Functional guilds · Isotopic niche · Magellan Strait · Stable isotope · Subpolar . Trophic ecology

\section{Introduction}

Shallow-water-mixed sediment bottoms are common coastal habitats in the sub-Antarctic Magellan region (Ríos 2007; Newcombe and Cárdenas 2011). In general, these benthic communities are characterized by high diversity, high abundance and high biomass (Ríos and Gerdes 1997; Gutt et al. 1999; Ríos et al. 2007). Within this habitat, the widespread kelp forest formed by the brown macroalgae Macrocystis pyrifera plays a significant structuring role. Apparently this kelp forest offers specific microhabitats as well as food resources for the zoobenthos, causing a positive correlation between Macrocystis presence and zoobenthic diversity, abundance and biomass (Santelices and Ojeda 1984; Vásquez and Buschmann 1997; Adami and Gordillo 1999; Gerdes and Montiel 1999; Ríos et al. 2007). M. pyrifera kelp forests cover almost $30 \%$ of the ca. 11,000-km-long Magellan coastlines (i.e. sub-Antarctic Fueguian channels and fjords south of the Strait of Magellan), thus being a dominant community-structuring feature in this region (Arntz 1999; Gerdes and Montiel 1999; Ríos et al. 2007). In contrast to Northern hemisphere kelp forests, where herbivorous sea urchins constitute the major controlling force of kelp abundance and distribution, echinoids play no significant structuring role in the Magellan region (Castilla and Moreno 1982; Santelices and Ojeda 1984; Vásquez and Buschmann 1997).

Little is known about Magellan intertidal and subtidal rocky community structure. Suspension-feeding species dominate and develop high biomass where environmental 
conditions are favourable (Cattaneo-Vietti et al. 1999), and particularly the dominance of mussels and limpets seems to be characteristic for these communities (Cattaneo-Vietti et al. 1999; Ríos and Mutschke 1999). Newcombe and Cárdenas (2011) found that similar physical conditions led to similar benthic assemblages and that the shading effect produced by $M$. pyrifera appears to be a strong structuring factor.

Based on gut content data, Guzmán and Ríos (1986) constructed a simple food web of the typical Magellan boulder and cobble intertidal community that consisted of three trophic levels. The upper trophic level was represented by turbellarians, nemerteans, asteroids and fish. Grazing gastropods (e.g. Nacella deaurata, N. magellanica) and filter-feeding bivalves (e.g. Aulacomya atra, Mytilus chilensis, Perumytilus purpuratus) dominated the intermediate trophic level, and detritus, microalgae and suspended particulate organic matter constituted the primary food sources.

Some trophic pathways within M. pyrifera kelp forests have been described in the Beagle Channel, at Tierra del Fuego Island. Based on trophic characteristics and associated species, Ojeda and Santelices (1984), Castilla (1985) and Adami and Gordillo (1999) developed a generalized trophic web of the M. pyrifera community by linking 20 taxa belonging to different functional groups like carnivores, which are best represented by asteroids; herbivores which include echinoids, amphipods and several species of gastropods; suspension feeders which include groups like sponges, bivalves and cirripedes; and detritus feeders which include decapod, ophiuroid and polychaete species.

So far, however, we lack a proper understanding of the general structural and functional organization of these subAntarctic marine communities. Knowledge and information about the complexity of interactions among organisms (i.e. behavioural and trophic relationships) and the stability/fluctuation of such structures over time and space are key topics to predict variation and future changes at the community level (Jacob 2005; Ríos 2007).

Stable isotope ratios of carbon and nitrogen $\left(\delta^{13} \mathrm{C}\right.$ and $\delta^{15} \mathrm{~N}$ ) are among the most suitable tools to describe the organic matter flow through the food web (e.g. Fry 1988; Wada et al. 1991) and to resolve trophic relationships in coastal ecosystems (e.g. Kaehler et al. 2000; Dunton 2001; Schaal et al. 2008; Leclerc et al. 2013). Furthermore, new approaches have provided the use of stable carbon and nitrogen isotope values to investigate community structure and niche occupancy (e.g. Bearhop et al. 2004; Jackson et al. 2011). In the present study, we used stable isotopes analysis (SIA) of $\delta^{13} \mathrm{C}$ and $\delta^{15} \mathrm{~N}$ to explore the trophic pathways and resource use of the benthic intertidal and kelp forest associated communities and to estimate the isotopic niche width of typical community members at two different sites in the sub-Antarctic Magellan Strait, Southern Chile.

The sites under study represent typical habitats characterizing the heterogeneous geomorphological conditions of the Magellan marine waters. These sites differ distinctly in their environmental conditions, particularly in the composition of the rocky substrate and the sites spanned a narrower geographical range $(<100 \mathrm{~km})$.

\section{Materials and methods}

\section{Study sites}

This study was carried out at Bahía Laredo (BL; $52^{\circ} 56.5^{\prime} \mathrm{S}$, $70^{\circ} 50^{\prime} \mathrm{W}$ ) and Punta Santa Ana (PSA; $53^{\circ} 38^{\prime} \mathrm{S}, 70^{\circ} 55^{\prime} \mathrm{W}$ ) (Fig. 1), which are about $100 \mathrm{~km}$ apart from each other. These two sites are located in the Paso Ancho basin, i.e. the wider section of the Strait of Magellan, which connects the Pacific and the Atlantic Ocean (Antezana 1999).

The Paso Ancho basin is characterized by high phytoplankton-standing stock (0.01-189 Chl $a \mu \mathrm{g} \mathrm{l}^{-1}$; Iriarte et al. 2001) and high primary production (125.7 $\mathrm{mgC} \mathrm{m} \mathrm{m}^{-2} \mathrm{~h}^{-1}$ maximum value registered; Magazzù et al. 1996) and a high share of invertebrate larvae in the copepod-dominated zooplankton during the spring bloom (Hamamé and Antezana 1999).

The sites BL and PSA were chosen based on their accessibility and on the presence of Macrocystis pyrifera kelps. According to Ríos et al. (2007), there are about 5.1 ha kelp forest in BL located between 5 and $8 \mathrm{~m}$ water depth with an average density of 0.16 holdfasts $\mathrm{m}^{-2}$. At PSA, kelp covers an area of about 2.1 ha $(5-8 \mathrm{~m}$ water depth) with an average density of 0.25 holdfasts $\mathrm{m}^{-2}$. BL is situated on the western shore of the Strait of Magellan. At this bay, the intertidal habitat is characterized by boulders and cobbles, which are slightly exposed to wave action. This habitat structure provides refuges to macrofaunal species, which find, under boulders, protection against wave impact and predators. At this site, mussel beds constitute the dominant biogenic structure (see Guzmán 1978; Guzmán and Ríos 1987; Ríos and Gerdes 1997). Sea surface temperatures range between 1.5 and $14.0{ }^{\circ} \mathrm{C}$ annually (Ríos et al. 2007).

At PSA, the habitat is structured by patchy bedrock platforms, which are moderately exposed to strong wind and wave action. The intertidal and subtidal of this site are dominated by benthic macroalgae and mussels. Water temperature varies between $1.0{ }^{\circ} \mathrm{C}$ in winter and $12.0{ }^{\circ} \mathrm{C}$ in summer (Ríos et al. 2007).

Ríos (2007) reports that at both BL and PSA the presence of $M$. pyrifera indicates more or less sheltered 


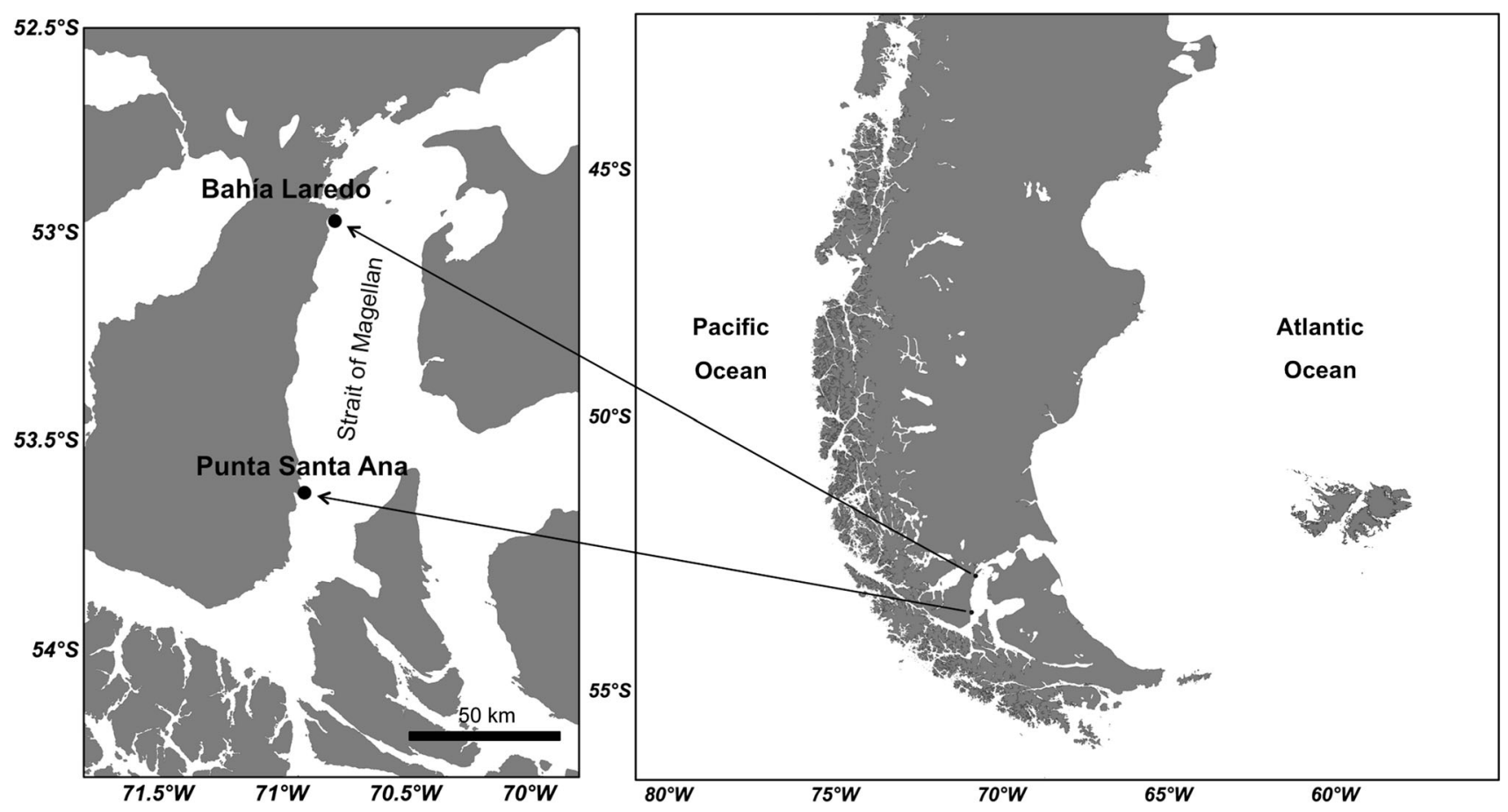

Fig. 1 Location of the study sites (black circles) in the Strait of Magellan, Chile

conditions where the predominantly south-easterly winds cause little hydrodynamic stress for the kelp forest.

\section{Sampling}

Sampling was carried out between January and February 2009 (austral summer). At each site, samples of macroalgae, sediment, invertebrates, fishes, shorebird faeces and bird feathers from the intertidal zone were collected by hand during low tide between upper and lower tidal limits. From the subtidal zone, samples were collected by SCUBA diving in 2-8 $\mathrm{m}$ depth inside the $M$. pyrifera kelp forests.

All samples collected were stored as whole immediately after collection at the Instituto de la Patagonia (Universidad de Magallanes) in Punta Arenas at $-20{ }^{\circ} \mathrm{C}$ prior to analysis at the Alfred Wegener Institute (AWI), Germany.

\section{Stable isotope analysis $\left(\delta^{13} \mathrm{C}\right.$ and $\left.\delta^{15} \mathrm{~N}\right)$}

In the laboratory, frozen samples of fauna and flora were thawed and identified to species level whenever possible. Specimens were rinsed with distilled water. Muscle tissues were dissected from large individuals (e.g. bivalves, fishes), while the whole body was used in small individuals (e.g. isopods, polychaetes). For sea urchins, sea stars and brittle stars used the peristomial membrane, tube feet and body discs, respectively (see Table 1).
Samples for stable isotope analysis were prepared from single individuals, except in very small-sized species where several specimens were pooled to obtain sufficient sample mass (e.g. bryozoans, amphipods). All samples were lyophilized for $24 \mathrm{~h}$ at $60{ }^{\circ} \mathrm{C}$ in a Finn-Aqua Lyovac GT2E and then grounded into a fine powder. Each sample was acidified to remove $\mathrm{CaCO}_{3}$ in accordance with Fry (1988) and Jacob et al. (2005). Stable isotope analysis including the determination of carbon and nitrogen concentrations was carried out at the stable isotope laboratory of the Museum für Naturkunde in Berlin using a Delta V Plus isotope ratio mass spectrometer. Stable isotope ratios were expressed in the delta notion $\delta^{13} \mathrm{C}$ and $\delta^{15} \mathrm{~N}$ as the deviation from the conventional standard Pee Dee Belemnite (PDB) for carbon and air $\mathrm{N}_{2}$ for nitrogen in per mill (\%).

\section{Data analysis}

Analysis of variance (ANOVA) with Tukey's post hoc test on differences between means $(p \leq 0.05)$ was used to compare isotope ratios among carbon sources within and between BL and PSA sites.

Feeding guild assignments were made for each taxon based on field observations of feeding behaviour and literature sources dealing with close relatives (see Table 1). For each functional guild two-way ANOVA was used to examine differences among sites and within guild on stable isotope values. 


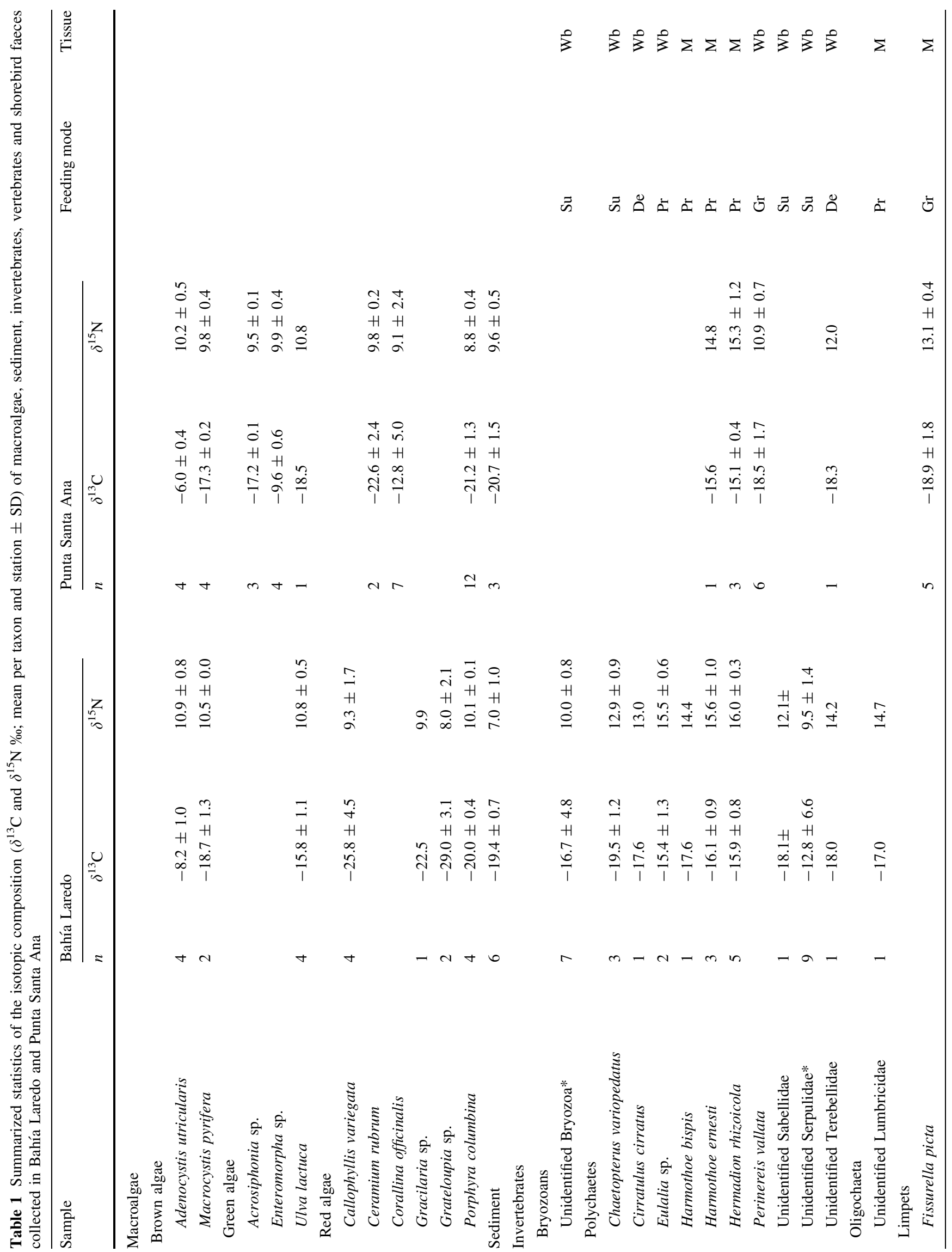




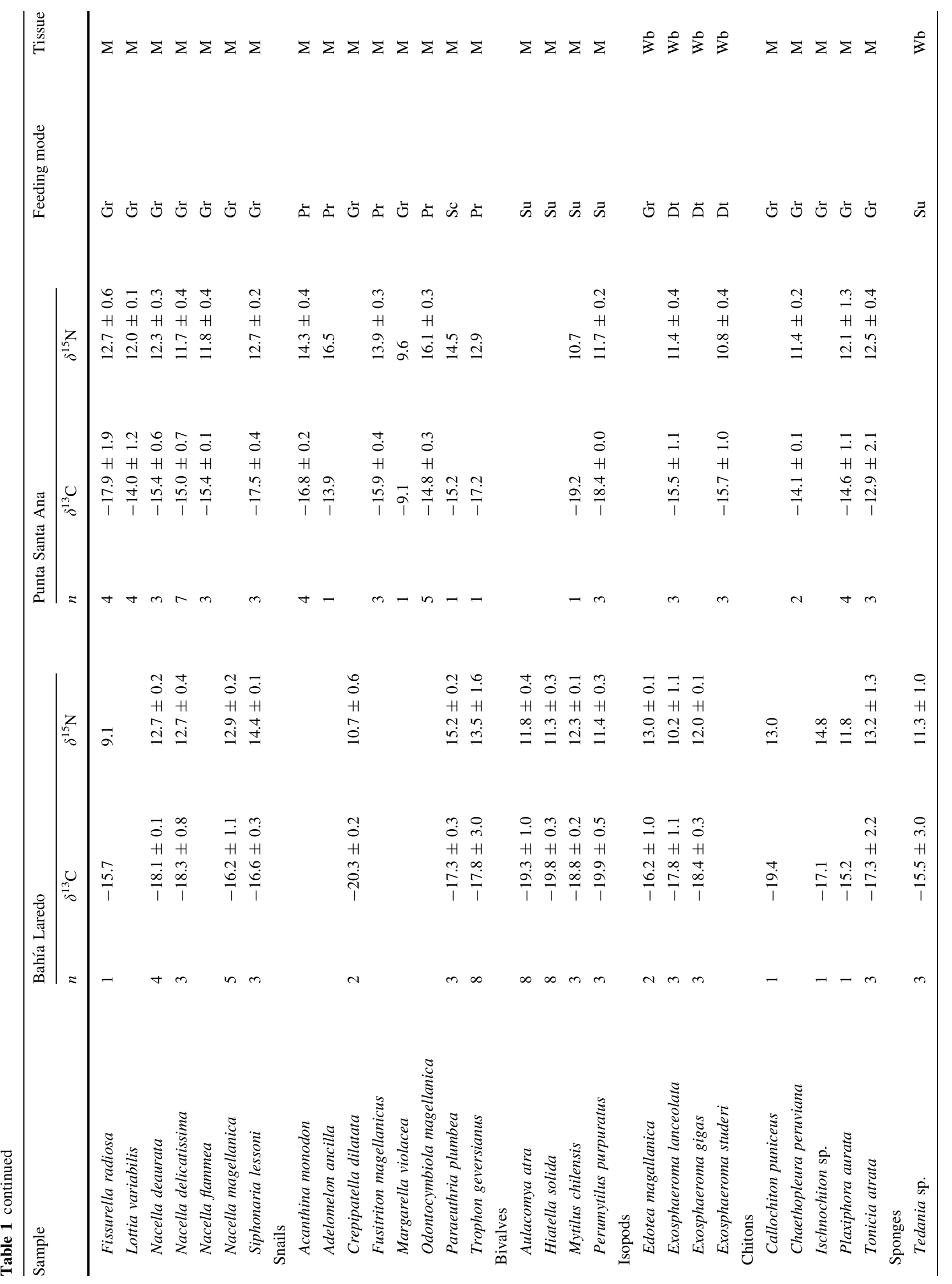




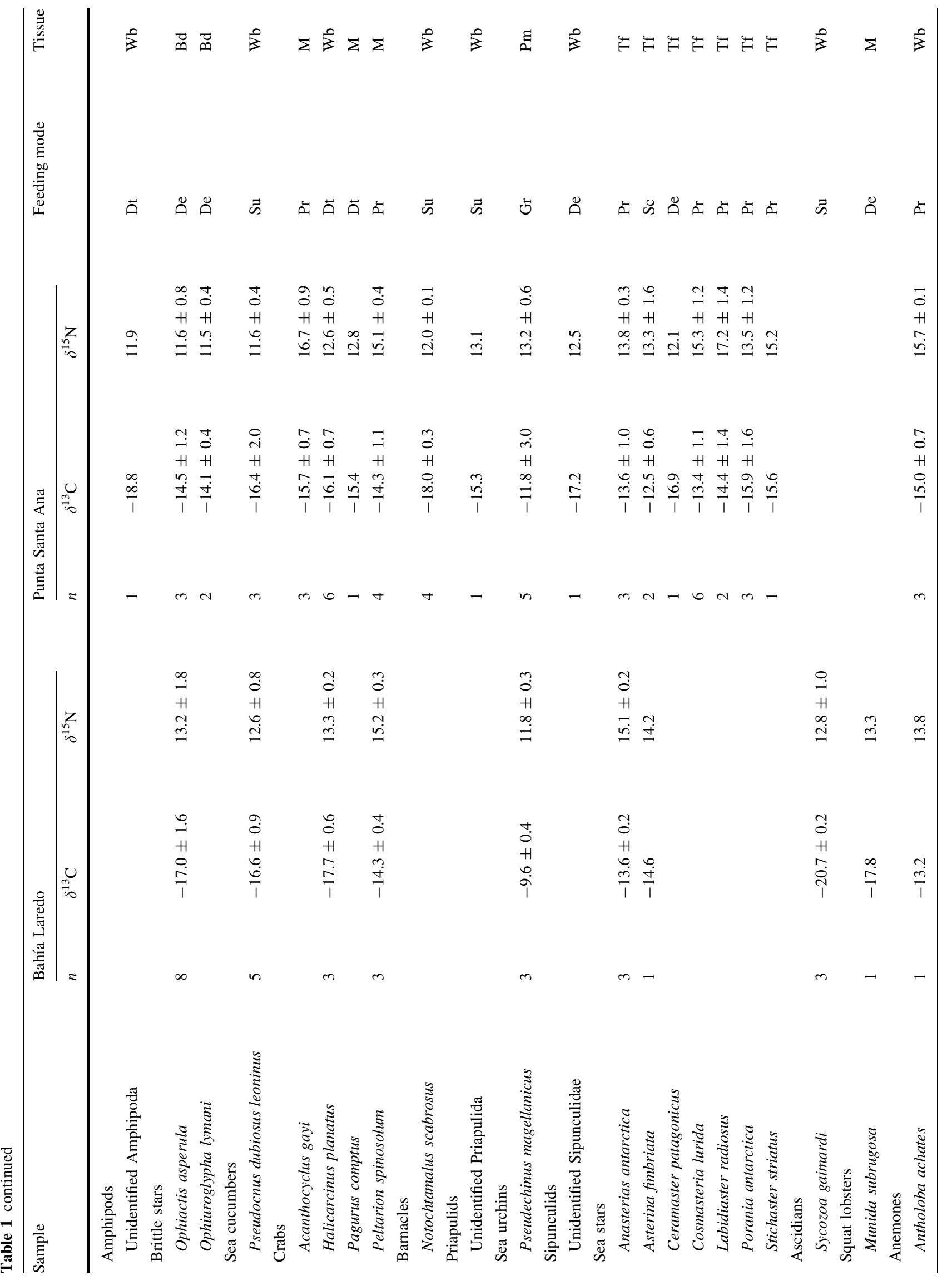




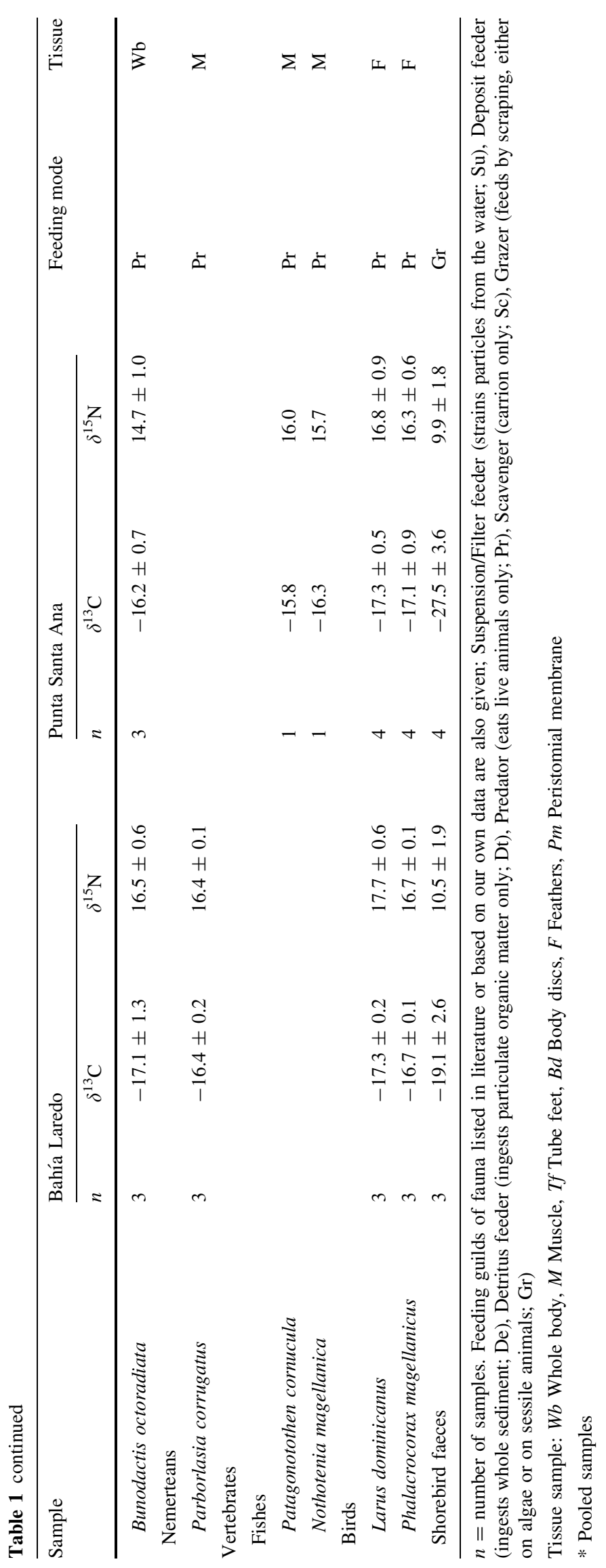


We used bi-plots of $\delta^{15} \mathrm{~N}$ versus $\delta^{13} \mathrm{C}$ (mean values of each functional guilds and carbon sources) to provide a general overview of the trophic structure and to identify possible trophic relations between food sources and consumers.

To assess whether the trophic community structure differs between sites, we established a geometric mean regression (GMR) model of mean $\delta^{15} \mathrm{~N}$ values of consumers present at BL versus mean $\delta^{15} \mathrm{~N}$ values of consumers present at PSA (see Ricker 1973, 1984). The parameters of the GMR were estimated from the following equations:

$b_{\mathrm{GMR}}=\frac{b}{r}, a_{\mathrm{GMR}}=\bar{Y}-b_{\mathrm{GMR}} \bar{X}$

where $b_{\mathrm{GMR}}$ was computed by dividing the slope $b$ of the least-squares predictive regression by the correlation coefficient of the relationship $r$ and the intercept $\left(a_{\mathrm{GMR}}\right)$ was calculated by substitution in the regression equation using the calculated slope and the mean values of $\bar{X}$ and $\bar{Y}$.

Consecutively, we estimated and compared isotopic niche width for each species present at both sites using standard ellipse areas corrected for small sample sizes (SEAc), method proposed by Jackson et al. (2011) who reformulated the Layman's et al. (2007) metrics. This analysis was done using SIBER (Stable Isotope Bayesian Ellipses in R, version 4.2; Jackson et al. 2011) routine, which is incorporated in the SIAR package (Stable Isotope Analysis in R, version 4.1.3; Parnell et al. 2010).

\section{Results}

We identified 46 species from 20 major taxa at BL and 55 species from 18 major taxa at PSA. In general, the BL community was characterized by polychaetes and limpets ( 5 species each), followed by bivalves, chitons, and red algae (4 species each). The PSA community included snails, sea stars and limpets, which were the most prominent taxa with seven species each, and less dominant species were polychaetes and crabs with four species each (Fig. 2).

The isotopic composition of carbon and nitrogen values of different sources of organic matter (i.e. benthic macroalgae and sediment as food sources), consumers (i.e invertebrates and vertebrates), and shorebird faeces at the two study sites are summarized in Table 1.

\section{Isotopic composition of potential food sources}

Among the food sources of the benthic community at BL, macroalgae $\delta^{13} \mathrm{C}$ values showed a relatively wide range from $-23.9 \pm 4.5 \%$ (red algae) to $-11.7 \pm 5.5 \%$ (brown algae). At PSA, macroalgae $\delta^{13} \mathrm{C}$ values ranged from $-18.5 \pm 5.1 \%$ (red algae) to $-11.7 \pm 6.0 \%$ (brown algae). We found that macroalgae $\delta^{13} \mathrm{C}$ values did not differ significantly among sites $(p>0.05)$, but within all macroalgae groups $(F=18.16, d f=2, p<0.0001)$. A post hoc Tukey's test confirmed that red algae showed significantly lower $\delta^{13} \mathrm{C}$ values.

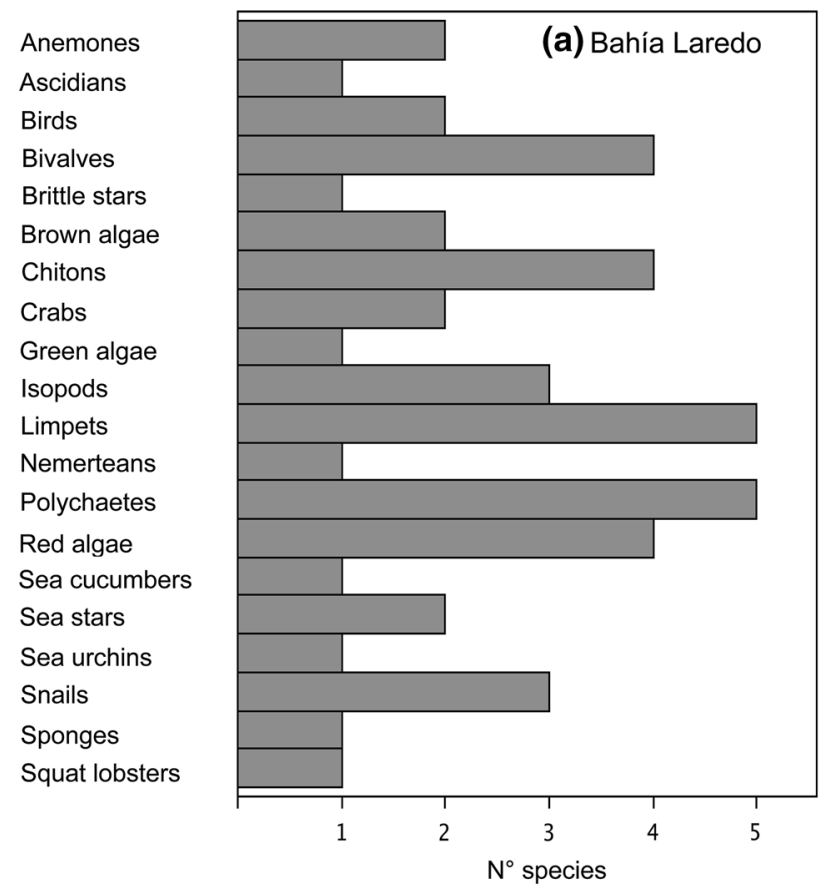

Anemones
Barnacles
Birds
Bivalves
Brittle stars
Brown algae
Chitons
Crabs
Fishes
Green algae
Isopods
Limpets
Polychaetes
Red algae
Sea cucumbers
Sea stars
Sea urchins
Snails

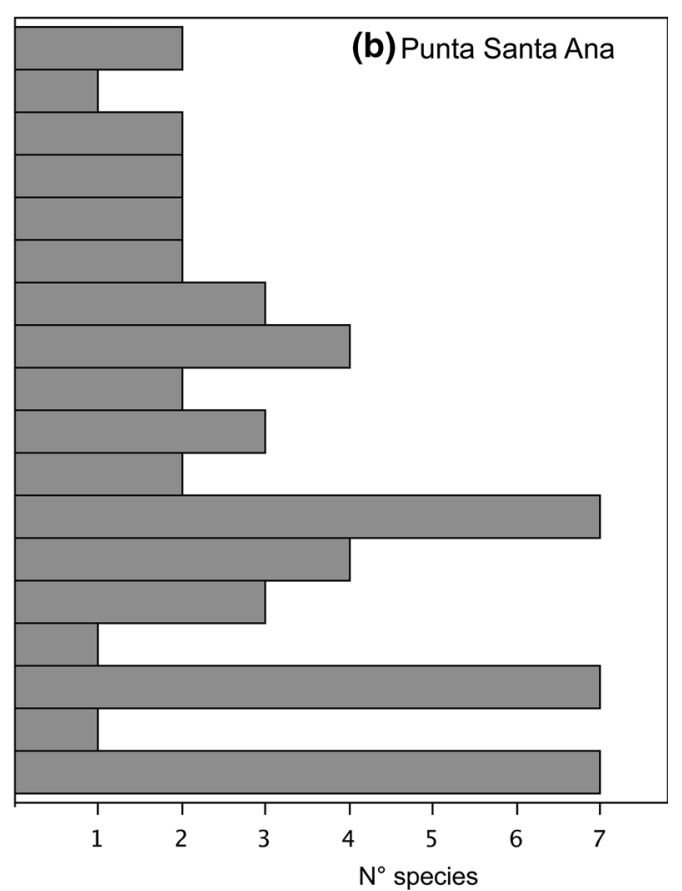

Fig. 2 Species numbers of flora and fauna at a Bahía Laredo and b Punta Santa Ana, in the Strait of Magellan. See Table 1 for complete species lists 
Fig. 3 Distribution of carbon and nitrogen stable isotope ratios (mean \pm standard deviation) among carbon sources and functional guilds at a Bahía Laredo and b Punta Santa Ana. See Table 1 for taxa belonging to each functional guild
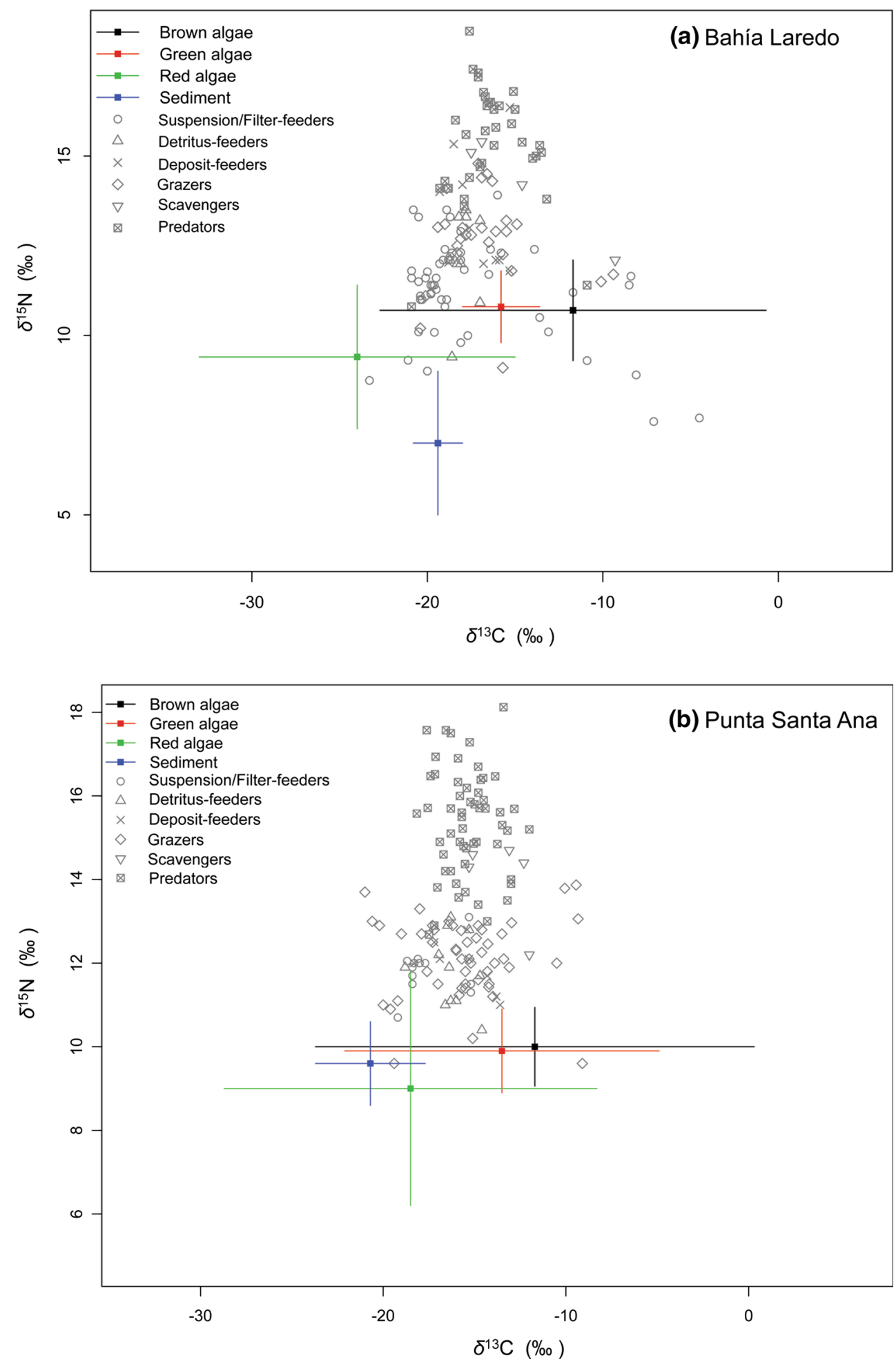

With regard to the macroalgae $\delta^{15} \mathrm{~N}$ values, these varied from $9.7 \pm 1.4 \%$ (red algae) to $10.7 \pm 0.7 \%$ (brown algae) at $\mathrm{BL}$ and from $9.0 \pm 1.4 \%$ (red algae) to $10.0 \pm 0.7 \%$ (brown algae) at PSA. We found that macroalgae $\delta^{15} \mathrm{~N}$ values differed among sites $(F=5.41$, $d f=1, p=0.0239)$ and within all macroalgae groups
$(F=5.50, d f=2, p=0.0068$; red algae) (see Table 1). A post hoc Tukey's test confirmed that red algae showed significantly lower $\delta^{15} \mathrm{~N}$ values.

Isotopic analysis of the organic matter associated with the sediment showed a mean $\delta^{13} \mathrm{C}$ value of $-19.4 \pm$ $0.7 \%$ at $\mathrm{BL}$ and a mean $\delta^{13} \mathrm{C}$ value of $-20.7 \pm 1.5 \%$ at 
PSA. These values did not differ significantly between sites. However, mean $\delta^{15} \mathrm{~N}$ values were significantly higher at PSA $(9.6 \pm 0.5 \%)$ than at BL $(7.0 \pm 1.0 \% ; F=$ $18.25, d f=1, p=0.0037)$.

\section{Isotopic composition of consumers}

Our data set of consumers includes 37 invertebrates and two vertebrates species sampled at BL. At PSA site, 43 invertebrate and four vertebrate species were sampled (see Table 1). Twenty-four consumers are present at both sites. The mean $\delta^{13} \mathrm{C}$ and $\delta^{15} \mathrm{~N}$ values of consumers averaged over the entire benthic food web at both sites are shown in Fig. 3a, b.

Among consumers of the benthic community at BL, the overall $\delta^{13} \mathrm{C}$ values ranged from $-20.7 \pm 0.2 \%$ (ascidian Sycozoa gaimardi) to $-9.6 \pm 0.4 \%$ (sea urchin Pseudechinus magellanicus), and $\delta^{15} \mathrm{~N}$ values ranged from $9.1 \%$ (limpet Fissurella radiosa) to $17.7 \pm 0.6 \%$ (kelp gull Larus dominicanus). At PSA, $\delta^{13} \mathrm{C}$ values ranged from $-18.9 \pm 1.8 \%$ (limpet Fissurella picta) to $-11.8 \pm$ $3.0 \%$ (sea urchin P. magellanicus) and $\delta^{15} \mathrm{~N}$ values ranged from $9.6 \%$ (snail Margarella violacea) to $17.2 \pm$ $1.4 \%$ (sunstar Labidiaster radiosus).

We found mainly not only birds (e.g. the kelp gull Larus dominicanus and the cormorant Phalacrocorax magellanicus) at BL as highest levels, but also large invertebrates at PSA (e.g. the sunstar Labidiaster radiosus, the crab Acanthocyclus gayi) (see Table 1).

Isotopic analyses of shorebird faeces $\delta^{13} \mathrm{C}$ values were significantly higher at BL $(-19.1 \pm 2.6 \%)$ compared to PSA $(-27.5 \pm 3.6 \%, F=11.48, d f=1, p=0.0195)$, whereas $\delta^{15} \mathrm{~N}$ values did not differ significantly $(10.5 \pm$ 1.9 and $9.9 \pm 1.8 \%$, respectively).

\section{Isotopic composition regarding functional guilds}

The BL community was dominated by grazers (12 species), predators (11 species) and suspension/filter feeders (8 species), while deposit feeders (3 species), detritus feeders (3 species) and scavengers (2 species) were less present. The PSA community was clearly dominated by predators (21 species) and grazers (13 species), while presence of suspension/filter feeders (4 species), detritus feeders (4 species), deposit feeders (3 species) and scavengers (2 species) were less present (see Table 1).

Among suspension/filter feeders, $\delta^{13} \mathrm{C}$ and $\delta^{15} \mathrm{~N}$ values did not differ significantly within guilds, and among sites, the overall mean was $-17.5 \pm 4.1 \%$ at $\mathrm{BL}$ and $-17.6 \pm$ $1.5 \%$ at PSA, and $11.3 \pm 1.4 \%$ at BL and $11.8 \pm 0.6 \%$ at PSA, respectively.

Among benthic grazers, $\delta^{13} \mathrm{C}$ and $\delta^{15} \mathrm{~N}$ values were significantly different within guild $\left(\delta^{13} \mathrm{C}: \quad F=8.60\right.$, $d f=18, \quad p<0.0001, \quad \delta^{15} \mathrm{~N}: \quad F=5.63, \quad d f=18, \quad p<$ 0.0001 ), and no significant differences in $\delta^{13} \mathrm{C}$ values were found among sites; however, $\delta^{15} \mathrm{~N}$ values were significantly higher at BL than PSA $(F=4.48, d f=1, p=$ $0.0374)$. The overall mean $\delta^{13} \mathrm{C}$ was $16.5 \pm 2.8 \%$ at BL and $-15.5 \pm 2.8 \%$ at PSA. Mean $\delta^{15} \mathrm{~N}$ was $12.7 \pm$ $1.2 \%$ at BL and $12.1 \pm 0.9 \%$ at PSA.

Among deposit feeders, $\delta^{13} \mathrm{C}$ and $\delta^{15} \mathrm{~N}$ values did not differ significantly within guild, and no significant differences were found in $\delta^{13} \mathrm{C}$ values among sites, but $\delta^{15} \mathrm{~N}$ values did differ among sites $(F=5.14, d f=1$, $p=0.0376)$. The overall mean $\delta^{13} \mathrm{C}$ was $-17.2 \pm 1.5 \%$ at BL and $-15.6 \pm 1.7 \%$ at PSA. Mean $\delta^{15} \mathrm{~N}$ was $13.3 \pm 1.6 \%$ at BL and $11.9 \pm 0.6 \%$ at PSA.

Among detritus feeders, $\delta^{13} \mathrm{C}$ values did not differ significantly within guild, but $\delta^{15} \mathrm{~N}$ values did differ significantly $(F=10.36, d f=5, p=0.0002)$, and only $\delta^{13} \mathrm{C}$ values were significantly different among sites $(F=18.52$, $d f=1, p=0.0004)$. The overall mean $\delta^{13} \mathrm{C}$ was $-17.9 \pm$ $0.6 \%$ at BL and $-16.1 \pm 1.1 \%$ at PSA. Mean $\delta^{15} \mathrm{~N}$ was $12.2 \pm 1.4 \%$ at BL and $11.9 \pm 0.9 \%$ at PSA.

Among scavengers, $\delta^{13} \mathrm{C}$ values were significantly different within guild and sites $\left(\delta^{13} \mathrm{C}: F=14.52, d f=2\right.$, $\left.p=0.0050, \quad \delta^{15} \mathrm{~N}: \quad F=9.52, \quad d f=1, \quad p=0.0177\right)$, although $\delta^{15} \mathrm{~N}$ values did not differ within guild and among sites. The overall mean $\delta^{13} \mathrm{C}$ was $-16.6 \pm 1.4 \%$ at BL and $-13.6 \pm 1.6 \%$ at PSA. Mean $\delta^{15} \mathrm{~N}$ was $15.0 \pm$ $0.5 \%$ at $\mathrm{BL}$ and $14.0 \pm 1.0 \%$ at PSA.

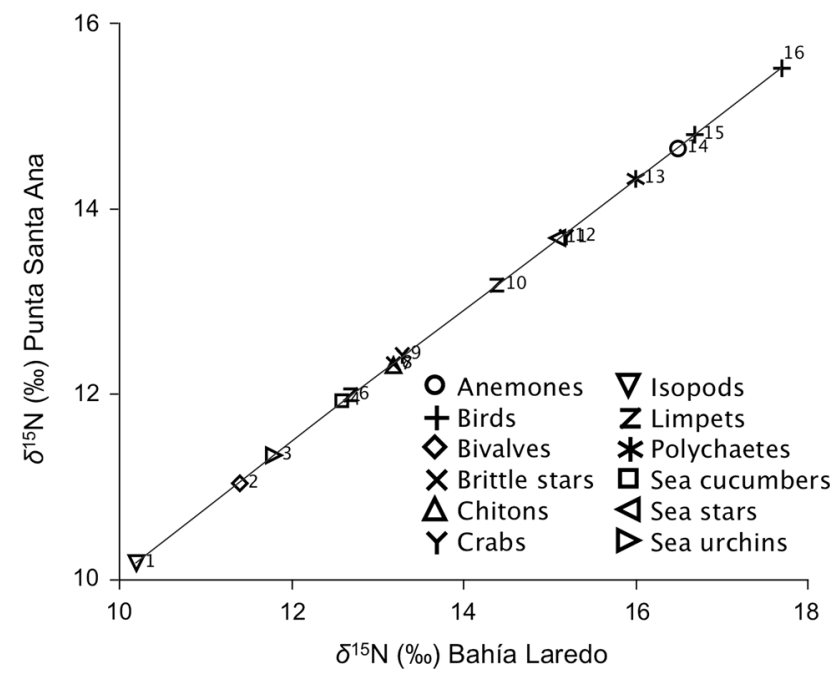

Fig. 4 Trophic relationship between same species at both sites: $\delta^{15} \mathrm{~N}_{\mathrm{PSA}}=2.9911+0.7069 \delta^{15} \mathrm{~N}_{\mathrm{BL}}, N=16, r^{2}=0.9998$, intercept $95 \%$ CI 2.9180-3.0641, slope $95 \%$ CI 0.7017-0.7121; $p<0.0001$. $1=$ Exosphaeroma lanceolata, $2=$ Perumytilus purpuratus, $3=$ Pseudechinus magellanicus, $4=$ Pseudocnus dubiosus leoninus, $5=$ Nacella deaurata, $6=$ Nacella delicatissima, $7=$ Tonicia atrata, $8=$ Ophiactis asperula, $9=$ Halicarcinus planatus, $10=$ Siphonaria lessoni, $11=$ Anasterias antarctica, $12=$ Peltar ion spinosolum, $13=$ Hermadion rhizoicola, $14=$ Bunodactis octoradiata, 15 = Phalacrocorax magellanicus, $16=$ Larus dominicanus 
Fig. 5 Isotopic niche width of same species present at a Bahía Laredo and b Punta Santa Ana. Solid lines enclose the standard ellipse area (SEA), representing the isotopic niche of consumer. Dotted lines are the convex hulls representing the total niche width of the different consumer. Hrhizo = Hermadion rhizoicola, Ndeaur = Nacella deaurata, Ndelic $=$ Nacella delicatissima,

Slesso = Siphonaria lesson, Ppurpu = Perumytilus purpuratus,

Elanceo = Exosphaeroma lanceolata , Tatrat $=$ Tonicia atrata, Oasper $=$ Ophiactis asperula,

Pmagel $=$ Pseudechinus magellanicus,

Pdubio $=$ Pseudocnus dubiosus leoninus,

Hplana $=$ Halicarcinus planatus, Pspino $=$ Peltarion spinosolum,

Aantar $=$ Anasterias antarctica,

Boctor $=$ Bunodactis octoradiata,

Phmagel $=$ Phalacrocorax magellanicus, Ldomin $=$ Larus dominicanus
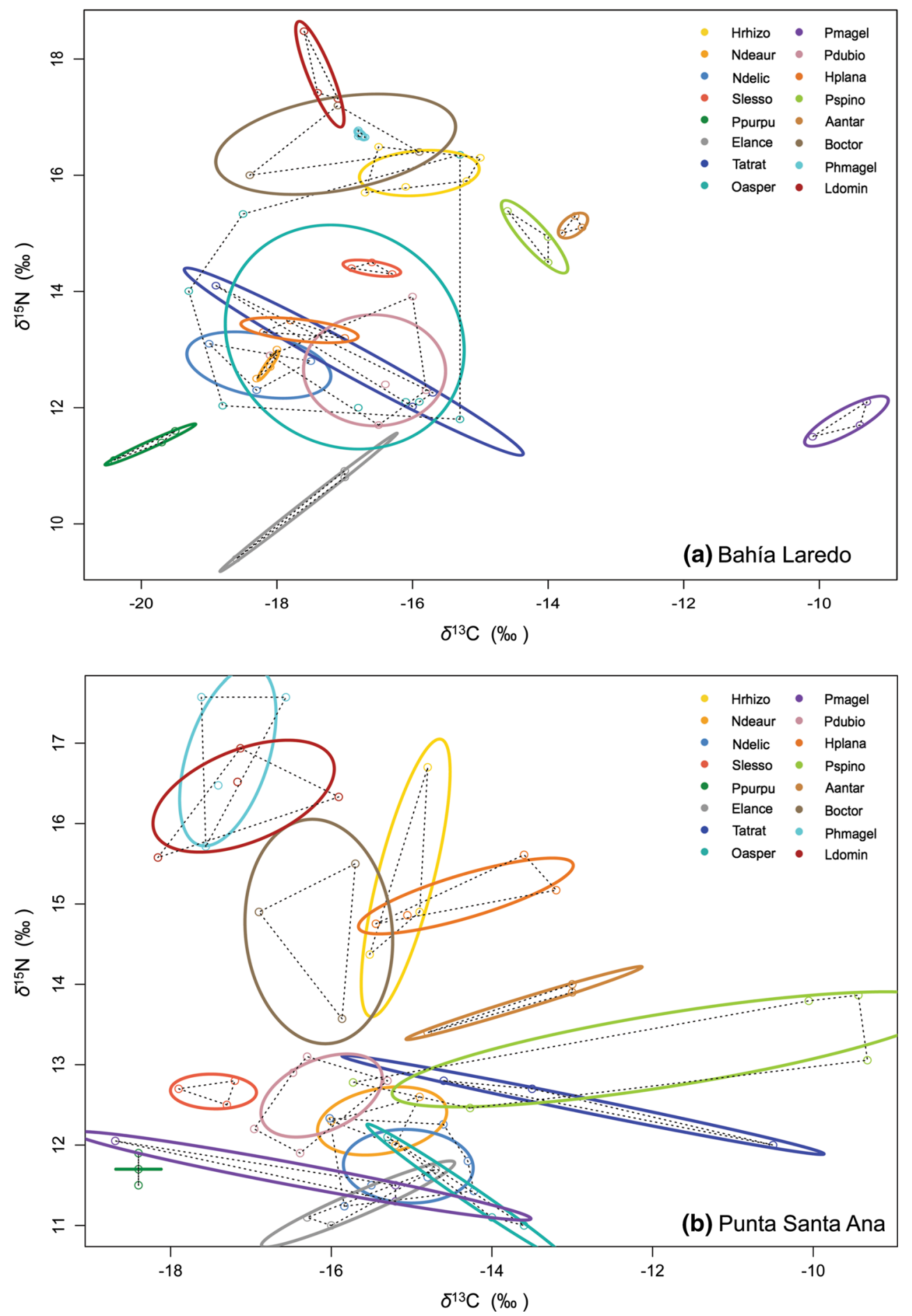

Among predators, $\delta^{13} \mathrm{C}$ and $\delta^{15} \mathrm{~N}$ values were significant different within guild $\left(\delta^{13} \mathrm{C}: F=2.21, d f=25, p=\right.$ $0.0055, \delta^{15} \mathrm{~N}: F=5.51, d f=25, p=0.0001$ ), and only $\delta^{13} \mathrm{C}$ values were significantly different among sites $(F=8.04, d f=1, p=0.0056)$. The overall mean $\delta^{13} \mathrm{C}$ was $-16.4 \pm 2.0 \%$ at BL and $-15.4 \pm 1.4 \%$ at PSA. Mean $\delta^{15} \mathrm{~N}$ was $15.4 \pm 1.6 \%$ at BL and $15.3 \pm 1.3 \%$ at PSA.

\section{Trophic structure and isotopic niche}

The consumer $\delta^{13} \mathrm{C}$ values were relatively aligned between $\delta^{13} \mathrm{C}$ values of food sources at both sites (Fig. 3a, b). The consumer $\delta^{15} \mathrm{~N}$ values cover a range of $8.6 \%$ in BL and $7.6 \%$ in PSA, respectively, i.e. at both sites the community is organized across three trophic levels. 
The slope of the geometric mean regression of $\delta^{15} \mathrm{~N}$ values at PSA versus BL was significantly different from one $($ slope $=0.7069$, intercept $=2.9911, p<0.0001$ ), indicating different trophic relationships between the same species at both sites (Fig. 4).

Analyses of isotopic niche width measured as the standard ellipse area (SEAc) of the same species present at both sites indicate niche variation in some species. For the species Phalacrocorax magellanicus $(\mathrm{SEAc}=0.02), \mathrm{Na}$ cella deaurata $(\mathrm{SEAc}=0.04)$, Halicarcinus planatus $(\mathrm{SEAc}=0.13)$, and Perumytilus purpuratus $(\mathrm{SEAc}=$ 0.15 ), a narrow trophic niche was observed at BL and similarly, $H$. planatus $(\mathrm{SEAc}=0.33$ ), and $S$. lessoni $(\mathrm{SEAc}=0.36)$ at PSA (Fig. 5a,b). The species Perumytilus purpuratus was present in a unique niche space at PSA.

At BL, the brittle star Ophiactis asperula had the largest niche observed with a SEAc of 10.6, followed by the anemone Bunodactis octoradiata with a SEAc of 4.5 , the sea cucumber Pseudocnus dubiosus leoninus with a SEAc of 3.15, and the chiton Tonicia atrata with a SEAc of 2.37 (Fig. 5a).

At PSA, a wide trophic niche was observed for the crab Peltarion spinosolum with a SEAc of 5.02, followed by Bunodactis octoradiata with a SEAc of 4.02, Larus dominicanus with a SEAc of 2.16 and the polychaete Hermadion rhizoicola with a SEAc of 1.93 (Fig. 5b).

We observed a niche overlap between the species $\mathrm{Na}$ cella deaurata and Nacella delicatissima at both sites.

\section{Discussion}

\section{Food sources}

Our macroalgae $\delta^{13} \mathrm{C}$ fall well in the wide $\delta^{13} \mathrm{C}$ range from -3 to $-35 \%$ reported elsewhere (e.g. Thayer et al. 1978; Fischer and Wiencke 1992; Raven et al. 2002). Macroalgal $\delta^{15} \mathrm{~N}$ values, however, showed much less variability (8.0-10.9\%o), as commonly observed in temperate coastal environments (Fredriksen 2003; Schaal et al. 2010).

The $\delta^{13} \mathrm{C}$ values indicate that brown algae, green algae and the organic matter associated with sediment constituted potential food sources for the benthic community at both BL and PSA sites, whereas red algae seem to be of little significance (Fig. 4a, b). Consumers may prefer brown and green algae owing to their higher nutritional value as compared to red algae (see discussion in Adin and Riera 2003). The very negative $\delta^{13} \mathrm{C}$ values recorded here for some red algae confirm earlier data from higher latitudes (see Hobson et al. 1995; Dunton 2001; Gillies et al. 2012). These outstandingly low values are likely to be related to assimilation of $\mathrm{CO}_{2}$ as source of inorganic carbon during photosynthesis (Raven et al. 2002).
Furthermore, extreme high $\delta^{13} \mathrm{C}$ values were found, in particular, for the brown algae Adenocystis utricularis at both sites (see Table 1). These results were very close to those previously found in the Antarctic Peninsula by Fischer and Wiencke (1992). Raven et al. (2002) found, on the basis of isotopic studies, that macroalgae with $\delta^{13} \mathrm{C}$ values higher than $-10 \%$ have the ability to use bicarbonate as an inorganic carbon source during the photosynthetic process.

Our sediment $\delta^{13} \mathrm{C}$ largely reflect either a mixture of macroalgae, particulate organic matter (POM) of pelagic origin (Cattaneo-Vietti et al. 1999) or marine surface sediments since $\delta^{13} \mathrm{C}$ values coincide with those reported from the Magellan Strait $(-19.77$ and $-22.17 \%$ ) by Aracena et al. (2011). This result is important since the sediment have been proposed to be an energy source for the heterotrophic benthic organisms (Graf 1992; Cattaneo-Vietti et al. 1999).

Macroalgae and carrion transported by wind and waves into the study areas may constitute a further source of sediment POM. Such import was observed at BL in particular and will affect sediment $\delta^{13} \mathrm{C}$ values. This import of organic material would be relevant for the $\delta^{15} \mathrm{~N}$ values. Our sediment $\delta^{15} \mathrm{~N}$ are comparable to $\delta^{15} \mathrm{~N}$ values reported for marine organic matter produced by phytoplankton, which range between 3 and $8 \%$ (Peters et al. 1978), while POM of the Chilean fjords ranges between 7.7 and $11.5 \%$ (Sepúlveda et al. 2011).

\section{Insights from isotopic composition to consumers feeding ecology}

Most of the primary consumers had $\delta^{13} \mathrm{C}$ and $\delta^{15} \mathrm{~N}$ values in the range of brown algae, green algae and sediment at both sites (Fig. 3a, b). This suggests that primary consumers-and probably to the whole benthic food webdepend on a mixture of different food sources.

Benthic suspension/filter feeders such as bivalves, ascidians and some polychaetes (e.g. Chaetopterus variopedatus) showed $\delta^{13} \mathrm{C}$ values that correspond to those of phytoplankton derived POM in general (e.g. between -18 and $-22 \%$; Goericke and Fry 1994). The higher $\delta^{13} \mathrm{C}$ for bryozoans, sponges, sea cucumbers, priapulids and serpulids, in comparison with those of bivalves, may indicate that they are not restricted to feeding on suspended POM. Bryozoans, for instance, are known to capture smaller heterotrophic organisms like microprotozoans (see, e.g. Winston 1978; Sokolowski et al. 2014). Moreover, some of these animals may be able to shift from suspension feeding to deposit feeding, conditional of the environment and the availability of suspended POM (Taghon et al. 1980). It is likely that higher $\delta^{13} \mathrm{C}$ and $\delta^{15} \mathrm{~N}$ values observed in some taxa are related to a facultative feeding by a share of zooplankton in their diets (e.g. Corbisier et al. 2004). 
Our data indicate a varied diet for benthic grazers, predominated by macroalgae. For example, the limpets $N$. deaurata and $N$. delicatissima show $\delta^{13} \mathrm{C}$ values close to kelp Macrocystis pyrifera at BL, indicating that these species graze directly on the kelp algae. However, another common gastropod, the limpet $N$. magellanica showed distinctly higher $\delta^{13} \mathrm{C}$ values, probably corresponding to green algae or microphytobenthos (not analysed in the present study). Recent work by Andrade and Brey (2014) based on gut content analysis found that the limpets $N$. deaurata and N. magellanica can feed on meiofauna, green microalgae, brown and red algae, and thus they may be considered to be omnivorous grazers. Apparently few consumers strongly prefer green algae at BL, e.g. the keyhole limpet Fissurella radiosa and the chiton Plaxiphora aurata. However, at PSA, these species seem to prefer other food sources, which indicate a certain alimentary flexibility. Our findings, however, contradict earlier studies from northern Chile that found species of the genus Fissurella to be omnivorous (Camus et al. 2009, 2013)

Apparently, red algae are of minor importance as food source for the communities studied here, despite their distinct presence in the habitat. However, some of the red algae species may be utilized as food. $\delta^{13} \mathrm{C}$ of the grazing gastropod Crepipatella dilatata $(-20.3 \pm 0.2 \%$ ) is suspiciously close to $\delta^{13} \mathrm{C}$ of the red algae Porphyra columbina $(-20.0 \pm 0.4 \%$ ) at BL. Many different food sources have been reported for Crepipatella spp. such as marine phytoplankton, macroalgae detritus, angiosperms, benthic diatoms and suspended POM (e.g. Chaparro et al. 2002; Decottignies et al. 2007), and hence the low $\delta^{13} \mathrm{C}$ value observed here may originate from other sources than that particular alga.

At PSA, other grazers like some limpets of the genus Nacella, the limpet Lottia variabilis and some chitons like Tonicia atrata showed also $\delta^{13} \mathrm{C}$ values close to red algae, specifically to the coralline algae Corallina officinalis (see Table 1). Several studies mentioned the importance of coralline algae as a food source for herbivores (e.g. Steneck 1982; Maneveldt et al. 2006). Hence, overall red algae may play a trophic role in the benthic community, since these macroalgae are conspicuous members of the Magellan Strait benthic communities (Newcombe et al. 2012).

The high $\delta^{13} \mathrm{C}$ of the small pink sea urchin P. magellanicus does not match those of its diets as documented by Penchaszadeh et al. (2004) (e.g. barnacles, bivalves, polychaetes) and occasional carrion (Andrade pers. obs.). $P$. magellanicus may feed on an extremely enriched carbon source such as the brown algae $A$. utricularis at BL, but at PSA it must consume some other food which has not been covered by this study. According to Penchaszadeh et al. (2004), P. magellanicus is extremely flexible in its alimentation and will adapt to the local conditions quite opportunistically.

Deposit feeders such as brittle stars, some polychaetes (e.g. unidentified Terebellidae), sipunculids and the squat lobster Munida subrugosa show intermediate $\delta^{13} \mathrm{C}$ values, which could reflect various food sources. Most likely the narrow $\delta^{13} \mathrm{C}$ and $\delta^{15} \mathrm{~N}$ indicate similar feeding strategies in all these taxa/species.

Detritus feeders such as amphipods, isopods, the crabs H. planatus and Pagurus comptus show $\delta^{13} \mathrm{C}$ values that probably reflects a mixed diet consisting of macroalgae detritus and microphytobenthos (e.g. - 14 and -16\%; Fry and Sherr 1984). Amphipods and isopods are known to utilize epiphytic microalgae too (e.g. Jaschinski et al. 2008). $\delta^{13} \mathrm{C}$ values of the crab $H$. planatus match with values reported by Riccialdelli et al. (2013) and support field observations that this species feeds on microphytobenthos (Guzmán and Ríos 1986).

Scavengers, i.e. taxa such as the gastropod Paraeuthria plumbea and the sea star Asterina fimbriata displayed intermediate $\delta^{13} \mathrm{C}$ values, which may indicate a generalist feeding strategy. Gut contents of the Buccinidae gastropod P. plumbea contain significant amounts of detritus (e.g. Guzmán and Ríos 1986; Andrade unpubl. data). In the field, P. plumbea fed largely on isopods and death carrion (Andrade pers. obs.). Because carrion is a rare food source at the coast (Britton and Morton 1994), P. plumbea is an opportunist feeder most likely, with the ability to both scavenge and actively predate. Dietary studies are lacking for the sea star A. fimbriata.

Predator $\delta^{13} \mathrm{C}$ values suggest a varied diet based on both benthic invertebrates and fish. According to literature, sea stars prey on mussels mainly (e.g. Castilla 1985), but our $\delta^{13} \mathrm{C}$ values suggest a preference for limpets in our communities. $\delta^{13} \mathrm{C}$ and $\delta^{15} \mathrm{~N}$ values of the crabs Acanthocyclus gayi and Peltarion spinosolum indicate a wider range of food items, like small crustaceans, isopods, chitons, brittle stars and benthic polychaetes. There is one study on $A$. gayi diet (Navarrete and Castilla 1988), indicating polychaetes, bivalves and barnacles as food items. On the other hand, $A$. gayi has been reported to be preyed upon by the sea kelp gull Larus dominicanus (Bahamondes and Castilla 1986), and $P$. spinosolum by the cormorant Phalacrocorax diet (Bulgarella et al. 2008). Our data suggest that mollusks in general are important food items for L. dominicanus while Phalacrocorax magellanicus may prefer fish. This coincides with the observations of Pizarro et al. (2012) who characterize this bird as a strictly marine, piscivorous and scavenging species.

$\delta^{13} \mathrm{C}$ of the muricid Trophon geversianus is close to bivalves, chitons and limpets, which does match, partially, with the prey spectrum observed by Andrade and Ríos (2007) (e.g. Mytilus chilensis, Aulacomya atra). The 
comparatively low $\delta^{15} \mathrm{~N}$ values may indicate an ontogenetic dietary shift. Accordingly, at young stages $(<30 \mathrm{~mm}$ of body length), the snail would feed on small prey, while at larger size especimen $(>50 \mathrm{~mm})$, appear to target much larger prey (Andrade and Ríos 2007). The few isotopic data available for the carnivorous snail Adelomelon ancilla and the anemone Antholoba achates (Zabala et al. 2013) are similar to the values obtained in the present study.

All fish species show quite similar isotopic values, suggesting rather similar diets. Our data for Patagonotothen cornucola are close to values reported for the closely related Patagonotothen spp. (Riccialdelli et al. 2013).

Shorebird faeces collected may correspond to the kelp goose Chloephaga hybrid, a bird that was observed during the fieldwork grazing on the shore. This species occurs in Patagonia, Tierra del Fuego and the Falkland Islands and is observed frequently to explore rocky shores or boulders during low tide (Weller 1972). $\delta^{13} \mathrm{C}$ of shorebird faeces were in the range of macroalgal $\delta^{13} \mathrm{C}$ i.e. these birds feed on large macroalgal resource. $\delta^{13} \mathrm{C}$ of shorebird faeces are higher at BL compared to PSA, indicating that the kelp Macrocystis pyrifera may constitute the base of this short food chain at BL, while red algae may occupy this position at PSA.

\section{Trophic structure and isotopic niche}

Our results indicate that the trophic structure of Magellan coastal benthic communities varies on a local scale $( \pm 100 \mathrm{~km})$. Although similar food sources and common consumer species were found at both sites, the food web structure varied distinctly, even if both sites share similar oceanographic characteristics (i.e. both are located at the Paso Ancho basin).

There is little information on the factors that structure these communities. Presumably, factors such as habitat complexity, heterogeneity and spatial variability in physical disturbance cause patchy spatial distribution patterns in benthic communities (Ríos 2007), and such patterns may account for the difference in source nitrogen between our study sites.

At both sites, we found significant differences in $\delta^{15} \mathrm{~N}$ of sediment and macroalgae. The lower sediment $\delta^{15} \mathrm{~N}$ values at BL may reflect a localized import of terrestrial organic matter by soil percolation from the coastal cliff (Andrade pers. obs.). However, differences in sediment grain size (Sampaio et al. 2010) may play a role too, since finer sediments are present at PSA (medium sand) than BL (boulder and cobbles with sandy patches Urban and Campos 1996). These results, could therefore affect the food availability for the consumers (e.g. Melville and Connolly 2003). We presume that differences in $\delta^{15} \mathrm{~N}$ at the base of the benthic food web provide the most robust explanation for the differences in the isotopic structure at both sites (see, e.g. Post 2002; Valls et al. 2014) and highly likely to be propagated to higher-order consumers levels in a nonlinear way, since trophic fractionation will vary greatly among species, across taxa, feeding mode or diet composition (Vander Zanden and Rasmussen 2001; Post 2002) or analysed tissue (Tieszen et al. 1983).

Thus, in several consumer taxa we see significantly higher $\delta^{15} \mathrm{~N}$ values at BL than PSA (e.g. shorebirds, anemones, polychaetes; see Fig. 4). Nonetheless, in most of the cases this difference did not exceed the average shift in $\delta^{15} \mathrm{~N}$ from one trophic level to the next (if we assume the commonly cited $3.4 \%$ trophic enrichment per trophic level, DeNiro and Epstein 1981; Minagawa and Wada 1984), suggesting that species from the study generally occupy similar trophic levels. For convenient reasons, we used the constant value of $3.4 \%$ for our interpretation since no information about trophic enrichment factors (TEFs) exists for the species inhabiting these systems, and further attempts to compile TEFs are needed for comparison across communities and make interpretations more carefully due to a variable ${ }^{15} \mathrm{~N}$-enrichment.

As indicated by the GMR analysis (Fig. 4), typical members of both communities differ in their $\delta^{15} \mathrm{~N}$ signature between the two sites. This is also visible in their isotopic niche width (Fig. 5a, b). We found considerable variation within species at both sites too. For example, the species Ophiactis asperula, Peltarion spinosolum, Tonicia atrata and Hermadion rhizoicola exhibit wide trophic niches that indicate a more generalists feeding behaviour. Most of these species are mobile (e.g. P. spinosolum, $T$. atrata), i.e. they are able to encounter a wider variability of prey items. However, the sessile anemone Bunodactis octoradiata seems to have a rather diverse alimentation too. In contrast, the sessile bivalve Perumytilus purpuratus occupies a small and unique niche space. The niche overlap between the grazers Nacella deaurata and Nacella delicatissima indicates similar food sources and rather a nonselective feeding.

The observed intra-specific differences may be due to individual variability in diet, differences in body size or even the age of the individuals (e.g. Bearhop et al. 2004; Newsome et al. 2007). These differences probably reflect dietary adjustments to local prey availability, i.e. an opportunistic foraging strategy (e.g. Gillies et al. 2012; Fanelli et al. 2013; Bessa et al. 2014).

Are Magellan communities a role model for future coastal communities on the Antarctic Peninsula? Continuing warming of the Antarctic Peninsula may shift environmental conditions further in the direction of current conditions in the Magellan region. Apparently, the similar trophic structure of Magellan coastal benthic communities and Antarctic Peninsula macroalgal communities (e.g. 
Dunton 2001; Jacob 2005; Mintenbeck 2008) indicate that a climate driver substitution of the Antarctic Peninsula by a Magellan community may not change much in terms of trophic structure and hence those functions depending on trophic structure.

This study provides a better understanding of benthic food web variability at local scales. This information may be important for further studies in accounting variations in biology patterns in marine benthic assemblages in the Magellan region.

Acknowledgments We thank the Laboratorio de Hidrobiología, Instituto de la Patagonia, Universidad de Magallanes for providing partly of the resources for this research. Special thanks go to Lic. Erika Mutschke who made the holdfast samples available for this study and to Dr. Américo Montiel who very kindly identified polychaetes samples. We thank Kerstin Beyer at AWI for her help during the sample preparation of the material for the Stable Isotopes Analyses. We also thank the editor and two anonymous reviewers for their comments, which helped improve this manuscript. This research was supported by a PhD fellowship (A0882368) to CA from the Deutscher Akademischer Austauschdienst (DAAD, Bonn, Germany) and the Comisión Nacional de Ciencia y Tecnología (CONICYT, Santiago, Chile).

\section{References}

Adami ML, Gordillo S (1999) Structure and dynamics of the biota associated with Macrocystis pyrifera (Phaeophyta) from the Beagle Channel, Tierra del Fuego. Sci Mar 63:183-191

Adin R, Riera P (2003) Preferential food source utilization among stranded macroalgae by Talitrus saltator (Amphipod, Talitridae): a stable isotopes study in the northern coast of Brittany (France). Estuar Coast Shelf Sci 56:91-98

Andrade C, Brey T (2014) Trophic ecology of limpets among rocky intertidal in Bahía Laredo, Strait of Magellan (Chile). An Inst Patagonia 42:65-70

Andrade C, Ríos C (2007) Estudio experimental de los hábitos tróficos de Trophon geversianus (Pallas 1774) (Gastropoda: Muricidae): selección y manipulación de presas. An Inst Patagonia 35:45-54

Antezana T (1999) Hydrographic features of Magellan and Fuegian inland passages and adjacent Subantarctic waters. Sci Mar 63:23-34

Aracena C, Lange C, Iriarte JL, Rebolledo L, Pantoja S (2011) Latitudinal patterns of export production recorder in surface sediments of the Chilean Patagonian fjords $\left(41-55^{\circ} \mathrm{S}\right)$ as a response to water column productivity. Cont Shelf Res 31:340-355

Arntz WE (1999) Magellan-Antarctic: ecosystems that drifted apart. Summary review. Sci Mar 63:503-511

Bahamondes I, Castilla JC (1986) Predation of marine invertebrates by the kelp gull Larus dominicanus in an undisturbed intertidal rocky shore of central Chile. Rev Chil Hist Nat 59:65-72

Bearhop S, Adams CE, Waldron S, Fuller RA, Macleod H (2004) Determining trophic niche width: a novel approach using stable isotope analysis. J Anim Ecol 73:1007-1012

Bessa F, Baeta A, Marques JC (2014) Niche segregation amongst sympatric species at exposed sandy shores with contrasting wrack availabilities illustrated by stable isotopic analysis. Ecol Indic 36:694-702
Britton JC, Morton B (1994) Marine carrion and scavengers. Oceanogr Mar Biol 32:369-434

Bulgarella M, Pizarro LC, Quintana F, Sapoznikow A, Gosztonyi A, Kuba L (2008) Diet of imperial cormorants (Phalacrocorax atriceps) and rock shags ( $P$. magellanicus) breeding sympatrically in Patagonia, Argentina. Ornitol Neotrop 19:553-563

Camus PA, Cid YY, Cisterna L, Cáceres CW (2009) Consumption and digestion of animal food by rocky intertidal herbivores: an evaluation of digestive flexibility and omnivory in three grazer species. Lat Am J Aquat Res 37:191-197

Camus PA, Arancibia PA, Ávila-Thieme MI (2013) A trophic characterization of intertidal consumers on Chilean rocky shores. Rev Biol Mar Oceanogr 48:431-450

Castilla JC (1985) Food webs and functional aspects of the kelp, Macrocystis pyrifera, community in the Beagle Channel, Chile. In: Siegfried WR, Condy PR, Laws RM (eds) Antarctic nutrient cycles and food webs. Springer, Berlin, pp 407-414

Castilla JC, Moreno CA (1982) Sea urchins and Macrocystis pyrifera: experimental test of their ecological relations in southern Chile. In: Lawrence JM (ed) Proceedings of the international echinoderm conference, Tampa Bay, Florida. Rotterdam, pp 257-263

Cattaneo-Vietti R, Chiantore M, Misic C, Povero P, Fabiano M (1999) The role of pelagic-benthos coupling in structuring littoral benthic communities at Terra Nova (Ross Sea) and in the Straits of Magellan. Sci Mar 63:113-121

Chaparro OR, Thompson RJ, Pereda SV (2002) Feeding mechanisms in the gastropod Crepidula fecunda. Mar Ecol Prog Ser 234:171-181

Corbisier TN, Petti MA, Skowronski RS, Brito TA (2004) Trophic relationships in the nearshore zone of Martel Inlet (King George Island, Antarctica): $\delta^{13} \mathrm{C}$ stable-isotope analysis. Polar Biol 27:75-82

Decottignies P, Beninger PG, Rincé Y, Robins RJ, Riera P (2007) Exploitation of natural food sources by two sympatric, invasive suspension-feeders: Crassostrea gigas and Crepidula fornicata. Mar Ecol Prog Ser 334:179-192

DeNiro MJ, Epstein S (1981) Influence of diet on the distribution of carbon isotopes in animals. Geochim Cosmochim Acta $45: 341-351$

Dunton KH (2001) $\delta^{15} \mathrm{~N}$ and $\delta^{13} \mathrm{C}$ measurements of Antarctic Peninsula fauna: trophic relationships and assimilation of benthic seaweeds. Am Zool 41:99-112

Fanelli E, Papiol V, Cartes JE, Rumolo P, López-Pérez C (2013) Trophic webs of deep-sea megafauna on mainland and insular slopes of the NW Mediterranean: a comparison by stable isotope analysis. Mar Ecol Prog Ser 490:199-221

Fischer G, Wiencke C (1992) Stable carbon isotope composition, depth distribution and fate of macroalgae from the Antarctic Peninsula region. Polar Biol 12:341-348

Fredriksen S (2003) Food web studies in a Norwegian kelp forest based on stable isotope $\left(\delta^{13} \mathrm{C}\right.$ and $\left.\delta^{15} \mathrm{~N}\right)$ analysis. Mar Ecol Prog Ser 260:71-81

Fry B (1988) Food web structure on Georges Bank from stable C, N, and S isotopic compositions. Limnol Oceanogr 33:1182-1190

Fry B, Sherr E (1984) ${ }^{13} \mathrm{C}$ measurements as indicators of carbon flow in marine and freshwater ecosystems. Contrib Mar Sci 27:13-47

Gerdes D, Montiel A (1999) Distribution patterns of macrozoobenthos: a comparison between the Magellan region and the Weddell Sea (Antarctic). Sci Mar 63:149-154

Gillies CL, Stark JS, Smith SDA (2012) Small-scale spatial variation of $\delta^{13} \mathrm{C}$ and $\delta^{15} \mathrm{~N}$ isotopes in Antarctic carbon sources and consumers. Polar Biol 35:813-827

Goericke R, Fry B (1994) Variations of marine plankton $\delta^{13} \mathrm{C}$ with latitude, temperature, and dissolved $\mathrm{CO}_{2}$ in the world ocean. Global Biogeochem Cy 8:85-90 
Graf G (1992) Benthic-pelagic coupling: a benthic view. Oceanogr Mar Biol Annu Rev 30:149-190

Gutt J, Helsen E, Arntz WE, Buschmann A (1999) Biodiversity and community structure of the mega-epibenthos in the Magellan region (South America). Sci Mar 63:155-170

Guzmán L (1978) Patrón de distribución espacial y densidad de Nacella magellanica (Gmelin, 1791) en el intermareal del estrecho de Magallanes (Mollusca, Gastropoda). An Inst Patagonia Ser Cienc Nat 9:205-219

Guzmán L, Ríos C (1986) Análisis de la estructura en comunidades intermareales del Cabo de Hornos: ambientes de bloques y cantos. Estud Oceanol 5:67-105

Guzmán L, Ríos C (1987) Age and growth of the Subantarctic limpet Nacella (Patinigera) magellanica magellanica (Gmelin, 1791) from the Strait of Magellan, Chile. Veliger 30:159-166

Hamamé M, Antezana T (1999) Chlorophyll and zooplankton in microbasins along the Strait of Magellan-Beagle Channel passage. Sci Mar 63:35-42

Hobson KA, Ambrose WG, Renaud PE (1995) Sources of primary production, benthic-pelagic coupling, and trophic relationships within the Northeast Water Polynya: insights from $\delta^{13} \mathrm{C}$ and $\delta^{15} \mathrm{~N}$ analysis. Mar Ecol Prog Ser 128:1-10

Iriarte JL, Kusch A, Osses J, Ruiz M (2001) Phytoplankton biomass in the sub-Antarctic area of the Straits of Magellan $\left(53^{\circ} \mathrm{S}\right)$, Chile during spring-summer 1997/1998. Polar Biol 24:154-162

Jackson AL, Inger R, Parnell AC, Bearhop S (2011) Comparing isotopic niche widths among and within communities: SIBERStable Isotope Bayesian Ellipses in R. J Anim Ecol 80:595-602

Jacob U (2005) Trophic dynamics of Antarctic shelf ecosystems-food webs and energy flow budgets. $\mathrm{PhD}$ thesis, University of Bremen, Bremen

Jacob U, Mintenbeck K, Brey T, Knust R, Beyer K (2005) Stable isotope food web studies: a case for standardized sample treatment. Mar Ecol Prog Ser 287:251-253

Jaschinski S, Brepohl DC, Sommer U (2008) Carbon sources and trophic structure in an eelgrass Zostera marina bed, based on stable isotope and fatty acid analyses. Mar Ecol Prog Ser 358:103-114

Kaehler S, Pakhomov EA, McQuaid CD (2000) Trophic structure of the marine food web at the Prince Edward Islands (Southern Ocean) determined by $\delta^{13} \mathrm{C}$ and $\delta^{15} \mathrm{~N}$ analysis. Mar Ecol Prog Ser 208:13-20

Layman CA, Arrington DA, Montanã CG, Post DM (2007) Can stable isotope ratios provide for community-wide measures of trophic structures? Ecology 88:42-48

Leclerc J, Riera P, Leroux C, Lévêque L, Davoult D (2013) Temporal variation in organic matter supply in kelp forests: linking structure to trophic functioning. Mar Ecol Prog Ser 494:87-105

Magazzù G, Panella S, Decembrini F (1996) Seasonal variability of fractionated phytoplankton, biomass and primary production in the Straits of Magellan. J Mar Syst 9:249-267

Maneveldt GW, Wilby D, Potgieter M, Hendricks MG (2006) The role of encrusting coralline algae in the diets of selected intertidal herbivores. J Appl Phycol 18:619-627

Melville AJ, Connolly RM (2003) Spatial analysis of stable isotope data to determine primary sources of nutrition for fish. Oecologia 136:499-507

Minagawa M, Wada E (1984) Stepwise enrichment of ${ }^{15} \mathrm{~N}$ along food chains: further evidence and the relation between $\delta^{15} \mathrm{~N}$ and animal age. Geochim Cosmochim Acta 48:1135-1140

Mintenbeck K (2008) Trophic interactions within high Antarctic shelf communities-food web structure and the significance of fish. $\mathrm{PhD}$ thesis, University of Bremen, Bremen

Navarrete SA, Castilla JC (1988) Foraging activities of Chilean intertidal crabs Acanthocyclus gayi Milne-Edwards et Lucas and A. hassleri Rathbun. J Exp Mar Biol Ecol 118:115-136
Newcombe EM, Cárdenas CA (2011) Rocky reef benthic assemblages in the Magellan Strait and the South Shetland Islands (Antarctica). Rev Biol Mar Oceanogr 46:177-188

Newcombe EM, Cárdenas CA, Geange SW (2012) Green sea urchins structure invertebrate and macroalgal communities in the Magellan Strait, southern Chile. Aquat Biol 15:135-144

Newsome SD, Martinez del Rio C, Bearhop S, Phillips DL (2007) A niche for isotopic ecology. Front Ecol Environ 5:429-436

Ojeda FP, Santelices B (1984) Invertebrate communities in holdfasts of the kelp Macrocystis pyrifera from southern Chile. Mar Ecol Prog Ser 16:65-73

Parnell AC, Inger R, Bearhop S, Jackson AL (2010) Source partitioning using stable isotopes: coping with too much variation. PLoS ONE 5:e9672

Penchaszadeh P, Bigatti G, Miloslavich P (2004) Feeding of Pseudochinus magellanicus (Philippi, 1857) (Echinoidea: Temnopleuridae) in the SW Atlantic Coast (Argentina). Ophelia 58:91-99

Peters KE, Sweeney RE, Kaplan IR (1978) Correlation of carbon and nitrogen stable isotope ratios in sedimentary organic matter. Limnol Oceanogr 23:598-604

Pizarro JC, Anderson CB, Rozzi R (2012) Birds as marine-terrestrial linkages in sub-polar archipelagic systems: avian community composition, function and seasonal dynamics in the Cape Horn Biosphere Reserve $\left(54-55^{\circ} \mathrm{S}\right)$, Chile. Polar Biol 35:39-51

Post DM (2002) Using stable isotopes to estimate trophic position: models, methods, and assumptions. Ecology 83:703-718

Raven JA, Johnston AM, Kübler JE, Korb R et al (2002) Mechanistic interpretation of carbon isotope discrimination by marine macroalgae and seagrasses. Funct Plant Biol 29:355-378

Riccialdelli L, Newsome SD, Dellabianca NA, Bastida R, Fogel ML, Goodall RNP (2013) Ontogenetic diet shift in Commerson's dolphin (Cephalorhynchus commersonii commersonii) off Tierra del Fuego. Polar Biol 36:617-627

Ricker WE (1973) Linear regressions in fishery sciences. J Fish Res Board Can 30:409-434

Ricker WE (1984) Computation and uses of central trend lines. Can J Zool 62:1897-1905

Ríos C (2007) Marine benthic communities of the Magellan region, Southern Chile: contribution of different habitats to the overall biodiversity. $\mathrm{PhD}$ thesis, University of Bremen, Bremen

Ríos C, Gerdes D (1997) Ensamble bentónico epifaunístico de un campo intermareal de bloques y cantos en Bahía Laredo, Estrecho de Magallanes. An Inst Patagonia Ser Cienc Nat 25:47-55

Ríos C, Mutschke E (1999) Community structure of intertidal boulder-cobble fields in the Straits of Magellan, Chile. Sci Mar 63:193-201

Ríos C, Arntz WE, Gerdes D, Mutschke E, Montiel A (2007) Spatial and temporal variability of the benthic assemblages associated to the holdfasts of the kelp Macrocystis pyrifera in the Straits of Magellan, Chile. Polar Biol 31:89-100

Sampaio L, Freitas R, Máguas C, Rodrigues A, Quintino V (2010) Coastal sediments under the influence of multiple organic enrichment sources: an evaluation using carbon and nitrogen stable isotopes. Mar Poll Bull 60:272-282

Santelices B, Ojeda P (1984) Effects of canopy removal on the understory algal community structure of coastal forest of Macrocystis pyrifera from southern South America. Mar Ecol Prog Ser 14:165-173

Schaal G, Riera P, Leroux C (2008) Trophic coupling between two adjacent benthic food webs within a man-made intertidal area: a stable isotopes evidence. Estuar Coast Shelf Sci 77:523-534

Schaal G, Riera P, Leroux C, Grall J (2010) A seasonal stable isotope survey of the food web associated to a peri-urban rocky shore. Mar Biol 157:283-294 
Sepúlveda J, Pantoja S, Hughen KA (2011) Sources and distribution of organic matter in northern Patagonia fjords, Chile ( $\left.\sim 44-47^{\circ} \mathrm{S}\right)$ : a multi-tracer approach for carbon cycling assessment. Cont Shelf Res 31:315-329

Sokolowski A, Szczepanska A, Richard P, Kedra M, Wolowicz M, Weslawski JM (2014) Trophic structure of the macrobenthic community of Hornsund, Spitsbergen, based on the determination of stable carbon and nitrogen isotopic signatures. Polar Biol 37:1247-1260

Steneck RS (1982) A limpet-coralline alga association: adaptations and defenses between a selective herbivore and its prey. Ecology 63:507-522

Taghon GL, Nowell ARM, Jumars PA (1980) Induction of suspension feeding in spionid polychaetes by high particulate fluxes. Science 210:562-564

Thayer GW, Parker PL, LaCroix MW, Fry B (1978) The stable carbon isotope ratio of some components of an eelgrass, Zostera marina, bed. Oecologia 35:1-12

Tieszen LL, Boutton TW, Tesdahl KG, Slade NA (1983) Fractionation and turnover of stable carbon isotopes in animal tissues: implications for $\delta^{13} \mathrm{C}$ analysis of diet. Oecologia 57:32-37

Urban HJ, Campos B (1996) Ecology of shallow-water bivalves. In: Arntz WE, Gorny M (eds) Cruise report of the Joint Chilean-
German-Italian Magellan “Victor Hensen” Campaign in 1994. Ber Polarforsch 190, pp 78-80

Valls M, Sweeting CJ, Olivar MP, de Puelles MF, Pasqual C, Polunin NVC, Quetglas A (2014) Structure and dynamics of food webs in the water column on shelf and slope grounds of the western Mediterranean. J Marine Syst 138:171-181

Vander Zanden MJ, Rasmussen JB (2001) Variation in $\delta^{15} \mathrm{~N}$ and $\delta^{13} \mathrm{C}$ trophic fractionation: implications for aquatic food web studies. Limnol Oceanogr 46:2061-2066

Vásquez JA, Buschmann AH (1997) Herbivore-kelp interactions in Chilean subtidal communities: a review. Rev Chil Hist Nat 70:41-52

Wada E, Mizutani H, Minagawa M (1991) The use of stable isotopes for food web analysis. Crit Rev Food Sci Nutr 30:361-371

Weller MW (1972) Ecological studies of Falkland Islands' waterfowl. Wildfowl 23:25-44

Winston JE (1978) Polypide morphology and feeding behaviour in marine ectoprocts. Bull Mar Sci 28:1-31

Zabala S, Bigatti G, Botto F, Iribarne O, Galván D (2013) Trophic relationship between a Patagonian gastropod and its epibiotic anemone revealed by using stable isotopes and direct observations. Mar Biol 160:909-919 